\title{
Pengaruh Pemberian Tandan Kosong Sawit dan Kapur Dolomit Sebagai Campuran Media Tanam Terhadap Pertumbuhan Bibit Kelapa Sawit ( Elaeis quenensis Jacq. ) di Main Nursery
}

\section{The Effect of Empty Bunch of Palm and Chalk of Dolomit Giving as Mixture of Plant Media to Growth of Palm Seedling ( Elaeis quenensis Jacq) in Main Nursery.}

\author{
Rahmawaty $^{1}$, Rustam Baraq Noor ${ }^{2}$ dan Hamidah ${ }^{2}$ \\ ${ }^{1}$ Alumni Program Studi Agroteknologi, Fakultas Pertanian, Universitas Widya Gama Mahakam \\ ${ }^{2}$ Tenaga Pendidik Program Studi Agroteknologi, Fakultas Pertanian, Universitas Widya Gama Mahakam \\ Jl. KH. Wahid Hasyim, Sempaja, Samarinda, Kalimantan Timur, Indonesia. \\ email : rahmaty@gmail.com, rusbnoor@gmail.com, hamidah_ardani@yahoo.co.id
}

Diterima : 5 April 2012 Disetujui : 2 Mei 2012

\section{ABSTRACT}

The Effect of Empty Bunch of Palm and Chalk of Dolomit Giving as Mixture of Plant Media to Growth of Palm Seedling (Elaeis quenensis Jacq) in Main Nursery. Target of research to know the effect of empty bunch of palm and chalk of dolomit giving as mixture of plant media to growth of palm seedling (elaeis quenensis jacq) in main nursery. The research was conducted on three months, since March until May 2010 in Palm plantation PT. Rea Kaltim Plantations, Perdana Village, Kembang Janggut District, Kutai Kertanegara Regent. The research was arranged in factorial completely randomized design (Factorial CRD) with factorial experimental design $3 \times 3$, and 3 replications. The first factor was the empty bunch of palm $(T)$, that consisted 3 levels, they were: $\left(t_{0}\right)=$ without the empty bunch of palm/polybag, $\left(t_{1}\right)=2 \mathrm{~kg}$ of the empty bunch of palm/polybag, $\left(t_{2}\right)=4 \mathrm{~kg}$ of the empty bunch of palm/polybag and the second factor was the chalk of dolomit $(K)$, that consisted 3 levels, they were: $\left(k_{0}\right)=$ without the chalk of dolomit /polybag, $\left(k_{1}\right)=0,2 \mathrm{~kg}$ of the chalk of dolomit /polybag, $\left(k_{2}\right)=0,4 \mathrm{~kg}$ of the chalk of dolomit /polybag. The result showed that the best result reached by $2 \mathrm{~kg}$ of the empty bunch of palm/polybag as mixture of plant media to growth of palm seedling ( Elaeis quenensis Jacq) in main nursery. The chalk of dolomit gave different result, treatment was not significantly influence because not be assisted with activator to quicken the empty bunch of palm dekomposition so that its result can be exploited for the growth of palm seedling. Each factor that was the empty bunch of palm and was the chalk of dolomit given separate factor to growth of palm seedling in main nursery.

Keywords: Bunch of Palm, Chalk of Dolomit and Growth of Palm Seedling

\section{PENDAHULUAN}

Perkembangan areal perkebunan di Kalimantan Timur dari tahun ke tahun mengalami peningkatan. Hal ini disebabkan adanya pembukaan areal perkebunan baru bagi pengembangan beberapa komoditi ekspor non migas yang menonjol seperti lada, coklat dan kelapa sawit. Kalimantan Timur mempunyai luas wilayah $245.238 \mathrm{Km}^{2}$ atau $1,5 \mathrm{kali}$ luas pulau Jawa dan Madura. Saat ini dan masa mendatang daerah ini akan berkembang dengan pesat karena, letaknya yang strategis, mempunyai sumberdaya alam yang melimpah dan iklim yang cukup kondusif. Pada saat ini pemerintah Kalimantan Timur telah menetapkan Kawasan Budidaya Non Kehutanan (KBNK), yang dapat digunakan untuk kegiatan pembangunan termasuk usaha perkebunan, yaitu seluas $\pm 5,32$ juta Ha. Dari luasan tersebut telah dikeluarkan atau diberikan ijin lokasi pada 188 perkebunan besar swasta (PBS) dengan areal seluas $\pm 3,146$ juta Ha, yang kondisi tanah dan agroklimat sesuai untuk usaha perkebunan, dan salah satunya adalah Kabupaten Kutai Kertanegara dengan areal KBNK 907.580 dan ijin lokasi untuk perkebunan adalah 433.662 pada tahun 2005. (Disbun Propinsi Kaltim, 2005).
Dalam pertanian modern saat ini, penggunaan pupuk kimia mulai ditekan penggunaannya, bahkan hampir ditiadakan dan digantikan dengan pupuk organik. Hal ini disebabkan pupuk organik tidak meninggalkan residu kimia, dimana salah satu pupuk organik adalah kompos. Pupuk kompos bukan hal yang baru bagi petani, nenek moyang kita sudah lama mengenalnya sejak berabad-abad silam, para leluhur kita sudah melakukan hal tersebut kurang lebih sama dengan praktek pengomposan modern (Musnawar, 2003). Menurut Indriani (2007), pemanfaatan tandan kosong sawit yang dijadikan kompos ini bermula dari banyaknya limbah padat organik yang proses dekomposisinya sangat lama dan perlunya areal yang luas untuk pembuangan limbah kelapa sawit tersebut.

Perkembangan industri pengolahan kelapa sawit di Indonesia pada era pembangunan ini sangat pesat pada tahun 1990 di Indonesia dijumpai 84 unit pabrik kelapa sawit yang mengolah 10 juta ton tandan buah segar dengan kapasitas yang bervariasi antara 220 - 600 ton tandan buah segar perjam (Renita, 2004). Selama proses pengolahan buah segar kelapa sawit menjadi minyak sawit diperoleh limbah baik berupa limbah cair maupun limbah padat. Limbah padat berupa tandan kosong dan cangkang kelapa sawit yang dapat diolah menjadi bahan yang 
berguna. Tandan kosong dibakar dan abu hasil pembakaran dapat dimanfaatkan sebagai pupuk, sedangkan cangkang kelapa sawit dibakar dan panas yang dihasilkan digunakan sebagai bahan baku industri yang aktif.Menurut Kuswandi (1993), Untuk mempercepat proses dekomposisi melalui pengaktifan mikroorganisme, serta mempercepat pelepasan unsur-unsur yang terkandung dalam tandan kosong, salah satunya adalah dengan pemberian kapur, selain itu kapur juga mempunyai beberapa keuntungan ; struktur tanahnya menjadi baik dan kehidupan mikroorganisme dalam tanah lebih giat, akibatnya daya melapuk bahan organik menjadi humus lebih cepat, kelarutan zat-zat yang sifatnya meracuni tanaman menjadi menurun dan unsur lain tidak

\section{BAHAN DAN METODE}

Penelitian ini dilaksanakan pada perkebunan kelapa sawit PT. Rea Kaltim Plantations di desa Perdana Kecamatan Kembang Janggut Kabupaten Kutai Kartanegara, selama 3 bulan mulai bulan Maret 2010 sampai dengan Mei 2010, dari pemindahan bibit ke dalam polibag hingga pengambilan data. Pelaksanaan penelitian meliputi ; persiapan media tanam, pemberian tandan kosong sawit dan kapur dolomite, penyiapan bibit kelapa sawit, penanaman (pemindahan bibit dari pre nursery ke main nursery), pemeliharaan (penyiraman, pemupukan, penyulaman dan peyiangan). Alat yang digunakan dalam penelitian ini adalah ; ayakan, cangkul, meteran, gembor, microkalifer, timbangan, bor tangan, alat-alat tulis dan kamera untuk dokumentasi. Bahan yang digunakan adalah bibit kelapa sawit tinera yang berumur 3 bulan, tandan kosong sawit (TKS) yang berumur \pm 3 bulan, kapur dolomit, tanah lapisan atas (top soil), polybag ukuran lebar $40 \mathrm{~cm}$, tinggi $50 \mathrm{~cm}$ dengan ketebalan 0,2 $\mathrm{mm}$. Penelitian ini disusun dalam Rancangan Acak Lengkap (RAL) faktorial dengan

\section{HASIL DAN PEMBAHASAN}

Berdasarkan hasil analisis sidik ragam menunjukkan bahwa perlakuan pemberian kapur dolomit sebagai campuran media tanam bibit kelapa sawit di main nursery tidak berpengaruh nyata terhadap parameter panjang akar, diameter batang umur 30 HST, Tinggi bibit umur 30 HST namun sangat berpengaruh nyata terhadap diameter batang umur 60, 90 HST, jumlah daun, tinggi bibit umur 60 HST serta berpengaruh nyata untuk parameter tinggi bibit umur $60 \mathrm{HST}$, jumlah akar, berat basah dan berat kering.

Belum berpengaruhnya penggunaan tandan kosong sawit (TKS) sebagai campuran media tanam pada tahap awal pertumbuhan bibit kelapa sawit diduga karena belum sempurnanya proses banyak terbuang, ditempat yang diberi kapur akan lebih leluasa ditanami berbagai jenis tanaman. Meningkatnya kesuburan fisik dan kimia tanah yang tercipta melalui pengapuran dan penambahan unsur hara yang cukup akan meningkatkan produktivitas dan pada akhirnya akan meningkatkan produksi tanaman yang dibudidayakan. Menurut Lingga dan Marsono (2003), setelah tanah pada kondisi yang baik maka pupuk merupakan kunci dari kesuburan tanah karena berisi satu atau lebih unsur untuk menggantikan unsur yang habis terserap tanaman. Jadi, memupuk berarti menambah unsur hara ke dalam tanah atau langsung pada tanaman melalui pupuk.

percobaan $3 \times 3$, tiap perlakuan sebanyak 3 ulangan, perlakuan terdiri dari 2 faktor yaitu pemberian tandan kosong sawit dan pemberian kapur dolomit. Faktor pertama adalah pemberian tandan kosong sawit (T) terdiri dari 3 taraf yaitu : $\mathrm{t}_{0}=$ tanpa tandan kosong sawit, $\mathrm{t}_{1}=2,00 \mathrm{~kg}$ tandan kosong sawit/polibag, $\mathrm{t}_{2}=4,00 \mathrm{~kg}$ tandan kosong sawit/polibag. Faktor kedua adalah perlakuan pemberian kapur dolomit $(\mathrm{K})$ juga terdiri atas 3 taraf yaitu : $\mathrm{k}_{0}=$ tanpa pemberian kapur, $\mathrm{k}_{1}=$ pemberian kapur $\quad 0,02 \mathrm{~kg} /$ polibag, $\mathrm{k}_{2}=$ pemberian kapur $0,04 \mathrm{~kg} /$ polibag. Pengambilan data meliputi ; tinggi bibit, diameter batang, jumlah pelepah Jumlah akar, panjang akar, berat basah, berat kering. Untuk melihat respon tanaman terhadap kedua perlakuan tersebut dilakukan analisis ragam, jika hasil analisis ragam menunjukan pengaruh yang nyata dari kedua perlakuan yang diberikan maka analisis dilanjutkan dengan Uji Beda Nyata Terkecil (BNT) pada taraf $5 \%$. Melalui uji BNT dapat diketahui perbedaan pengaruh antara tiap-tiap taraf pada masing-masing perlakuan.

dekomposisi tandan kosong sawit (TKS) yang diaplikasikan, sehingga fungsi tandan kosong sawit sebagai tambahan bahan organik tanah agar mampu mendorong pertumbuhan bibit kelapa sawit secara cepat belum tercapai. Sebagaimana pendapat Lelwakabesi (1988), yang menyatakan bahwa aspek ketersediaan unsur hara tanaman selain dipengaruhi oleh aspek penambahan termasuk didalamnya penambahan bahan organik juga sangat dipengaruhi oleh reaksi-reaksi sistem antara tanah, air dan tanaman itu sendiri, dalam hal ini khususnya menyangkut imobilisasi dan mobilisasi unsur hara pada proses dekomposisi bahan organik yang ada. Tidak berpengaruhnya 
Tabel 1. Rata-Rata Diameter Batang pada Perlakuan Pemberian Tandan Kosong Sawit

\begin{tabular}{cccc}
\hline \multirow{2}{*}{ Tandan kosong sawit } & \multicolumn{3}{c}{ Diameter Batang $(\mathrm{mm})$ pada Umur Tanaman } \\
\cline { 2 - 4 } & $30 \mathrm{hst}$ & $60 \mathrm{hst}$ & $90 \mathrm{hst}$ \\
\hline $\mathrm{t}_{0}$ & 1,83 & $2,97^{\mathrm{a}}$ & $4,16^{\mathrm{ab}}$ \\
$\mathrm{t}_{2}$ & 1,98 & $3,13^{\mathrm{a}}$ & $4,60^{\mathrm{a}}$ \\
$\mathrm{t}_{3}$ & 1,73 & $2,32^{\mathrm{b}}$ & $3,55^{\mathrm{b}}$ \\
\hline
\end{tabular}

Keterangan : Angka-angka yang diikuti huruf yang sama menunjukkan tidak berbeda nyata berdasarkan uji BNT pada taraf $\alpha=5 \%$

Tabel 2. Rata-Rata Jumlah Daun pada Perlakuan Pemberian Tandan Kosong Sawit

\begin{tabular}{cccc}
\hline \multirow{2}{*}{ Tandan kosong sawit } & \multicolumn{3}{c}{ Jumlah Daun (helai) pada Umur Tanaman } \\
\cline { 2 - 4 } & $30 \mathrm{hst}$ & $60 \mathrm{hst}$ & $90 \mathrm{hst}$ \\
\hline $\mathrm{t}_{0}$ & $7,67^{\mathrm{c}}$ & $8,11^{\mathrm{c}}$ & $10,56^{\mathrm{b}}$ \\
$\mathrm{t}_{2}$ & $8,44^{\mathrm{a}}$ & $9,33^{\mathrm{a}}$ & $11,67^{\mathrm{a}}$ \\
$\mathrm{t}_{3}$ & $8,11^{\mathrm{b}}$ & $8,78^{\mathrm{b}}$ & $10,67^{\mathrm{b}}$ \\
\hline
\end{tabular}

Keterangan : Angka-angka yang diikuti huruf yang sama menunjukkan tidak berbeda nyata berdasarkan uji BNT pada taraf $\alpha=5 \%$

Tabel 3. Rata-Rata Tinggi Bibit pada Perlakuan Pemberian Tandan Kosong Sawit

\begin{tabular}{cccc}
\hline \multirow{2}{*}{ Tandan kosong sawit } & \multicolumn{3}{c}{ Tinggi Bibit $(\mathrm{cm})$ pada Umur Tanaman } \\
\cline { 2 - 4 } & $30 \mathrm{hst}$ & $60 \mathrm{hst}$ & $90 \mathrm{hst}$ \\
\hline $\mathrm{t}_{0}$ & 40,11 & $47,56^{\mathrm{b}}$ & $72,33^{\mathrm{b}}$ \\
$\mathrm{t}_{2}$ & 41,44 & $54,89^{\mathrm{a}}$ & $80,00^{\mathrm{a}}$ \\
$\mathrm{t}_{3}$ & 35,56 & $43,11^{\mathrm{c}}$ & $70,33^{\mathrm{b}}$ \\
\hline
\end{tabular}

Keterangan : Angka-angka yang diikuti huruf yang sama menunjukkan tidak berbeda nyata berdasarkan uji BNT pada taraf $\alpha=5 \%$

penggunaan tandan kosong sawit (TKS) sebagai campuran media tanam terhadap pertumbuhan akar pada akhir pengamatan diduga bukan karena bahan organik dari tandan kosong sawit (TKS) tersebut tidak memberikan dampak positif terhadap pertumbuhan akar khususnya, namun diduga karena peran perbaikkan sifat fisik tanah seperti perubahan tekstur dan aerasi sudah cukup optimal dan merata pada setiap perlakuan pada percobaan ini. Baik perlakuan yang menggunakan tambahan bahan organik maupun yang tidak, karena pada dasarnya semua media yang digunakan untuk pembibitan kelapa sawit pada tahap main-nursery menggunakan tanah yang subur dan gembur. Selain itu karena pemupukan NPK diberikan di sekitar akar menyebabkan pertumbuhan akar tidak memanjang untuk menjangkau unsur hara yang tersedia dalam media tanam. Pengaruh pemberian tandan kosong sawit (TKS) sebagai campuran media tanam terhadap pertumbuhan akar diduga baru akan terlihat pada umur bibit diatas 90 hari setelah tanam (HST). Hal ini diyakini akan terjadi, karena fungsi tandan kosong sawit (TKS) sebagai upaya mempertahankan porositas tanah baru akan terlihat pada saat proses pembibitan semakin lama berjalan dan media di dalam polibag semakin padat. Pemadatan tanah tersebut terjadi akibat tekanan air penyiraman dan perkembangan akar tanaman yang terus aktif di dalam ruang yang terbatas. Dengan demikian media yang tidak diberikan tambahan bahan organik maka proses pemadatan ini akan menjadi hambatan pertumbuhan akar. Hal tersebut sejalan dengan pendapat Marsono dan Lingga (2003), yang menyatakan bahwa selain unsur hara mikro dan makro didalam tanah, pupuk organik telah terbukti sangat baik dalam perbaikkan struktur tanah pertanian. Hal tersebut dapat terjadi karena organisme tanah saat penguraian bahan organik ke dalam bentuk pupuk bersifat sebagai perekat dan dapat mengikat butir-butir tanah menjadi butiran yang lebih besar.

Berdasarkan hasil analisis sidik ragam menunjukkan bahwa perlakuan pemberian kapur dolomit sebagai campuran media tanam bibit kelapa sawit di main nursery tidak berpengaruh nyata terhadap semua parameter yang diamati. Hal ini diduga karena waktu yang digunakan dalam pemberian kapur dolomit sebagai campuran media tanam terhadap pertumbuhan bibit kelapa sawit belum cukup optimal untuk memproses tandan kosong sawit menjadi bahan organik, selain itu pemberian kapur dolomit hanya berfungsi untuk menetralisir $\mathrm{pH}$ tanah. Pemberian kapur dolomit untuk pertumbuhan bibit kelapa sawit dapat digantikan dengan pemberian pupuk, mengingat tanaman kelapa sawit dapat tumbuh pada jenis tanah apapun. Menurut Lumbantoruan dan Surbakti (1996), tanaman kelapa sawit tidak memerlukan tanah dengan sifat kimia yang istimewa sebab kekurangan satu unsur hara dapat diatasi dengan pemberian pupuk. Tidak berpengaruhnya pemberian kapur dolomit 
sebagai campuran media tanam terhadap semua parameter diduga bukan berarti kapur dolomit tidak memberikan pengaruh baik terhadap pertumbuhan tanaman namun diduga dosis yang diberikan belum cukup untuk merangsang pertumbuhan bibit kelapa sawit.

Berdasarkan hasil analisis sidik ragam menunjukkan bahwa perlakuan pemberian tandan kosong kelapa sawit ditambah dengan kapur dolomit sebagai campuran media tanam bibit kelapa sawit di main nursery tidak berpengaruh nyata terhadap semua parameter yang diamati. Hal ini diduga karena masing-masing faktor memberikan faktor terpisah terhadap pertumbuhan bibit kelapa sawit. Sesuai pendapat Steel dan

\section{KESIMPULAN}

1. Berdasarkan hasil analisis sidik ragam menunjukkan bahwa perlakuan pemberian 2,00 $\mathrm{kg}$ tandan kosong sawit/polibag sebagai campuran media tanam pada pembibitan kelapa sawit di main-nursery akan memberikan pertumbuhan bibit kelapa sawit yang terbaik.

2. Perlakuan pemberian kapur dolomit tidak berpengaruh nyata karena tidak dibantu dengan

\section{DAFTAR PUSTAKA}

Disbun Propinsi Kaltim. 2005. Profil Investasi Usaha Perkebunan di Kalimantan Timur. Dinas Perkebunan Propinsi Kalimaantan Timur.

Indriani YH. 2007. Membuat Kompos Secara Kilat, Penebar Swadaya, Jakarta.

Kuswandi. 1993. Pengapuran Tanah Pertanian. Kanisius. Yogyakarta.

Leiwakabesi. F.M. 1998. Kesuburan Tanah. Jurusan Tanah Fakultas Pertanian Institut Pertanian Bogor. IPB Press Bogor.

Lingga, P. dan Marsono. 2003. Petunjuk Penggunaan Pupuk. Penebar Swadaya. Jakarta.
Torrie (1993), bahwa apabila dua faktor tidak berbeda nyata maka disimpulkan faktor tersebut bertindak bebas satu dengan lainnya.

Pemberian kapur dolomit sebagai campuran media tanam untuk mempercepat dekomposisi tandan kosong kelapa sawit tidak dapat optimal karena waktu dekomposisi yang terlalu singkat untuk merombak tandan kosong kelapa sawit tersebut. Oleh karena itu, pemberian tandan kosong kelapa sawit hanya berperan dalam perbaikan sifat fisik media tanam sedangkan pemberian kapur dolomit berperan dalam menetralisir asam sehingga masing-masing perlakuan bertindak sendiri-sendiri.

aktivator untuk mempercepat dekomposisi tandan kosong kelapa sawit sehingga dapat dimanfaatkan hasil rombakannya untuk pertumbuhan bibit kelapa sawit.

3. Masing-masing faktor yaitu faktor pemberian tandan kosong kelapa sawit dan pemberian kapur dolomit memberikan faktor terpisah terhadap pertumbuhan bibit kelapa sawit di main nursery.

Lumbantoruan dan Surbakti, 1996. Penanaman Kelapa Sawit dengan Lubang Tanaman Besar di Kebun Rambutan dan Sei Mengkei PTP. Nusantara III (Persero) Medan, PTP. Nusantara XIII, Pontianak.

Musnawar I. 2003. Pupuk Organik. Penebar Swadaya. Bogor.

Renita M. 2004. Proses Anaerobik sebagai alternatif untuk mengolah limbah sawit. Sumatra Utara

Steel, R.GD. dan J.H. Torrie. 1993. Prinsip dan Prosedur Statistika, Alihbahasa ; Bambang Sumantri, Gramedia Pustaka Utama, Jakarta. 